\section{Global Proceedings Repository \\ American Research Foundation}

ISSN 2476-017X

Available online at http://proceedings.sriweb.org

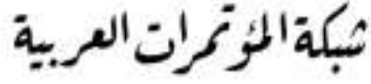

http://arab.kmshare.net/

The Ninth International Scientific Academic Conference

Under the Title "Contemporary trends in social, human, and natural sciences"

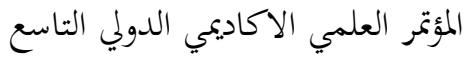

$$
\begin{aligned}
& \text { تحت عنوان "الاتحاهات المعاصرة في العلوم الاجتماعية، الانسانية، والطبيعية" } \\
& 17 \text { - } 18 \text { يوليو - تموز } 2018 \text { - اسطنبول - تركيا }
\end{aligned}
$$

http://kmshare.net/isac2018/

\title{
Do Palestinian workers' remittances from Israel matter for the Palestinian economy?
}

\author{
Islam Hassouneh ${ }^{\text {a }}$ \\ ${ }^{\text {a }}$ College of Administrative Science and Informatics, Palestine Polytechnic University (PPU), P.O. Box \\ 198, Abu-Ruman, Hebron, Palestine, \\ islamh@ppu.edu
}

\begin{abstract}
This paper studies the impact of Palestinian workers' remittances from Israel on Palestinian economic growth using quarterly data over the period 2000-2016. Stationary and cointegration tests as well as a vector error correction model are applied for such purpose. Cointegration tests provide evidence of a long-run positive equilibrium relationship between remittances and output growth. Results also indicate that remittances have influence on Palestinian economic development at both short- and long-run level.
\end{abstract}

JEL codes: C32, J01

Keywords: VECM, remittances, Palestine. 


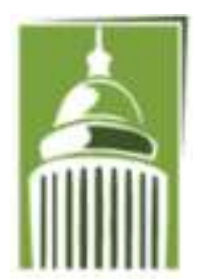

ARF

\section{Global Proceedings Repository \\ American Research Foundation}

ISSN 2476-017X

Available online at http://proceedings.sriweb.org

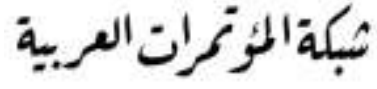

http://arab.kmshare.net/

\section{INTRODUCTION}

Remittances are considered as an important source of income for many countries, especially in developing countries. In 2016, developing countries received about $75 \%$ of all remittances and supply roughly $80 \%$ of the world's migrant workers. Workers' remittances, in developing countries, are the second largest source of foreign exchange earnings after foreign direct investment (World Bank, 2017).

The economy of Palestine is highly dependent on workers' remittance inflows, particularly from Israel. In 2013, personal remittance inflows to Palestine reached $\$ 2.3$ billion, of which $\$ 1.1$ billion were transferred by Palestinians working in Israel, making Palestine the seventh largest recipient of remittances in the world in terms of the percentage of remittances to Gross Domestic Product (GDP), 23\% of GDP (Saad, 2015). According to Palestinian Central Bureau of Statistics (PCBS, 2017), in 2016, 14\% of Palestinian employees were working in Israel, mainly in construction and agricultural sectors, generating an unprecedented level of remittances flows ( $\$ 1.4$ billion). This is equivalent to $17 \%$ of Palestinian GDP. In spite of the high number of Palestinian labors working in Israel, this number tends to depend largely on the political situation between Palestine and Israel. This paper sheds light on this issue by studying the impact of Palestinian workers' remittances from Israel on Palestinian economic growth over the period 2000-2016.

Empirical studies in the literature argues that the relationship among remittances and economic growth is still ambiguous. Results from previous studies can be categorized into three types: Positive relationship between remittances and economic growth, second negative relationship, and finally, no relationship. More specifically, Giuliano and Ruiz-Arranz (2009) study the links between remittances and economic growth in 100 developing countries and found that remittances boost growth in countries with less developed financial system, Chami et al., (2003) reveal that there exists a negative impact of remittances on economic growth, and Barajas et al. (2009) find that workers' remittances have no impact on economic growth. Despite the great number of studies conducted to investigate the impact of remittances on economic growth, no published studies have analyzed the impact of Palestinian workers' remittances from Israel on Palestinian economy, which represents a contribution of this work to the literature. To achieve the paper objective, stationary and cointegration tests as well as a Vector Error Correction Model (VECM) are applied

This paper is organized as follows. In the second section, we present a brief overview of remittances in Palestine. A literature review of previous research is presented in the third section. The fourth section is devoted to discussing econometric methods. The discussion of the results and the conclusion are presented in the fifth and sixth sections, respectively.

\section{REMITTANCES IN PALESTINE: AN OVERVIEW}

The establishment of Israel state in Palestine has made the Palestinian economy an exceptional economy. After the war of 1948, Israel occupied 76.7\% of the total area of Palestine and gained control over the rest of Palestinians' land in 1967, namely the West Bank and Gaza Strip in the course of the Six-Day war (Naksah). ${ }^{1}$ Israeli policy immediately following the Six-Day war strangled the Palestinian economy and increased its dependence on Israeli economy, i.e. Israel restricted trade within the Palestinian territories and opened its market to Palestinian labor without restrictions. This policy increased the flow of Palestinian workers to Israel and thus made remittances from Israel as a major source of income for Palestinian

\footnotetext{
${ }^{1}$ Readers interested in the Israeli-Palestinian conflict are referred to Hassouneh (2017), Smith (2010).
} 


\section{Global Proceedings Repository \\ American Research Foundation}

ISSN 2476-017X

Available online at http://proceedings.sriweb.org

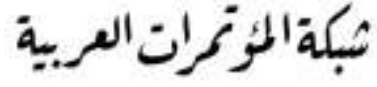

http://arab.kmshare.net/

economy. More specifically, between 1967 and until the early 1990s, more than one-third of the Palestinian labor force was employed in Israel, generating over a quarter of the Palestinian GDP (Farsakh, 1998). The high number of Palestinians working in Israel was mainly due to higher employment opportunities and wages.

Since the signing of the 1993 Oslo peace accords, significant changes in the pattern of policy began, i.e. the Israeli policy of border closures intensified and greater restrictions were placed on Palestinian workers wishing to enter Israel (Farsakh, 1998; Farsakh, 2002 and Lentin, 2008). As a result, the number of Palestinian workers going to Israel dropped from around 115 thousand in 1992 to less than 36 thousand in 1996. From 1997 and until the second Intifada in 28 September 2000, there was an increase in the Palestinian labor flows to Israel and Israeli settlements. According to PCBS (2017), the number of Palestinians working in Israel reached its peak of 135.7 thousand workers in the third quarter of 2000, just before the start of the second Intifada, generating around $\$ 323$ million of remittances (29\% of Palestinian GDP of the third quarter). ${ }^{2}$ Immediately following the second Intifada, Israel prevented 98.2 thousand Palestinian workers from reaching their former jobs. Specifically, the number of workers decreased from 135.7 thousand in the third quarter of 2000 to 37.5 thousand in the fourth quarter reducing income from remittances to $\$ 88.5$ million.

By the end of the second Intifada, an increase in the number of workers and thus in the remittance inflows to the Palestinian economy was observed. More specifically, the inflow of Palestinian workers' remittances from Israel increased from \$450.18 million in 2005 to \$771.38 million in 2010 and to \$1.40 billion in 2016. On the other hand, the real GDP in Palestine increased from $\$ 4.80$ billion in 2005 to 6.12 billion in 2010 and 8.03 billion in 2016. Hence, in Palestine, remittances were equal to about 17\% of GDP in 2016.

From the above information, we can observe that the inflow of remittances tends to depend largely on the political status between Palestine and Israel. It seems also that workers' remittances play an important role in the economy of Palestine. As already mentioned, this paper sheds light on this issue by studying the impact of Palestinian workers' remittances from Israel on Palestinian economic growth.

\section{LITERATURE REVIEW}

Analyzing the relationship between remittances and economic growth has gained special importance in the economics literature. Empirical analyses, however, have found that workers' remittances may have different impact on economic growth. More specifically, many empirical studies argue that economic growth is positively associated with remittances, especially in developing countries (Kandil and Metwally, 1990; Jongwanich, 2007; Pradhan et al., 2008; Giuliano and Ruiz-Arranz, 2009; Nsiah and Fayissa, 2011; Jouini, 2015; Mayer and Shera, 2017). Some other empirical studies find negative, or insignificant, impact of workers' remittances on economic growth (Chami et al., 2003; Waheed and Aleem, 2008; Jawaid and Raza, 2014; Spatafora, 2005; Barajas et al., 2009). More details are presented below.

Kandil and Metwally (1990) investigates the impact of remittances made by Egyptian migrants to their home country on the Egyptian country using standard Keynesian model over the period from 1970 to 1984. Their results suggest that remittances have a strong positive impact on the Egyptian economy. Jongwanich (2007) investigates the impact of remittances on economic growth and poverty in selected Asian and Pacific countries using panel data over the period 1993-2003. His results suggest that remittances have a relatively small positive impact on growth but a significant favourable impact on poverty reduction.

\footnotetext{
${ }^{2}$ Unless otherwise indicated, the information presented in this section was obtained from PCBS (2017).
} 


\section{Global Proceedings Repository \\ American Research Foundation}

ISSN 2476-017X

Available online at http://proceedings.sriweb.org

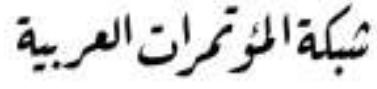

http://arab.kmshare.net/

Pradhan et al. (2008) assess the impact of workers' remittances on economic growth within 39 developing countries using panel data over the period 1980-2004. They estimate a standard growth model using both fixed-effects and random-effects approaches and find that remittances have a positive effect on economic growth. Giuliano and Ruiz-Arranz (2009) study the links between remittances and economic growth in 100 developing countries from years 1975-2002 using Ordinary Least Squares (OLS) and find that remittances can enhance economic growth in less financially developed countries.

The analysis by Nsiah and Fayissa (2011) investigates the relationship between economic growth and remittances through panel data of 64 different countries of African, Asian, and Latin American-Caribbean during the 1987-2007 period. They use a panel unit root and panel cointegration tests that capture the exact relationship between remittances and economic growth. Their findings suggest a positive relationship between remittances and output growth. Recently, Jouini (2015) analyses the relationship between remittances and economic growth of Tunisian economy over the period of 1970-2010. In doing so, he uses Autoregressive Distributed Lag (ARDL) approach. His results indicate that, although short-run linkages exist, no long-run relationships between remittances and economic growth exist. More recently, Mayer and Shera (2017) study the relationship between economic growth and remittances using panel data set of six high remittances receiving countries, Albania, Bulgaria, Macedonia, Moldova, Romania and Bosnia Herzegovina from 1999-2013. Their findings also suggest a positive relationship among the two variables. While the above literatures suggest a positive relationship among economic growth and remittances, some empirical studies provide evidence that remittances have a negative impact, or no effect, on economic growth. Chami et al. (2003) examine the effects of worker remittances on an economy growth of 113 countries over the period of 1970 to 1998 using multiple regression analysis. They emphasize the presence of moral hazard effect of remittances, which affects negatively the economic growth. The study by Waheed and Aleem (2008) investigates the impact of workers' remittances on economic growth in Pakistan using time series data from 1981 to 2006. Their findings suggest a significant negative relationship between workers' remittances and economic growth in the long run. Jawaid and Raza (2014) analyze the effect of workers' remittances and its volatility on economic growth of five South Asian countries by employing long time series data from 1975 to 2009. Cointegration test suggests a positive long run relationship between remittances and economic growth in India, Bangladesh, Sri Lanka and Nepal, but a negative relationship in Pakistan. Results also suggest that the volatility of workers' remittances has a negative effect on four economic growth countries, Pakistan, Indian, Bangladesh and Sri Lanka, and no impact in Nepal. Spatafora (2005) estimates a panel regression, of 87 countries during the period 1980-2003, to analyze the relationship between remittances and output growth and find no direct link between both variables. In the same context, Barajas et al. (2009) use a panel data on 84 countries during 1970-2004 and find that workers' remittances have no impact on economic growth.

Although a great number of studies have been made available recently, the literature that empirically assesses the relationships between economic growth and remittances in Palestine is relatively poor. Two notable studies on this topic are reviewed below. Astrup and Dessus (2005) develop a dynamic general equilibrium model to estimate the impact of restricted access to the Israeli labor market on the Palestinian export performance and, in turn, on economic growth. Their results suggest that exporting Palestinian labors to Israel tends to reduce strongly the capacity of the Palestinian industry to export goods. Results also indicate that the closure of the Israeli labor market negatively affects the Palestinian economy. The analysis by Saad (2015) investigates the effects of personal remittance inflows on key macroeconomic variables (private consumption, gross domestic investment, imports and output growth) during the period 1995-2013. To do so, he uses a Keynesian-type econometric model. His results show that remittance 


\section{Global Proceedings Repository \\ American Research Foundation}

ISSN 2476-017X

Available online at http://proceedings.sriweb.org

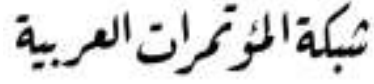

http://arab.kmshare.net/

inflows to the Palestinian economy significantly affected the macroeconomic variables and markedly contributed to the economic growth.

In spite of previous attempts to characterize Palestinian economic response to workers' remittance inflows, no previous analysis has directly investigated the effect of remittances from Israel on Palestinian GDP growth, a country that contributes of around 50\% of the total personal remittances in Palestine.

\section{ECONOMETRIC METHODS}

As well known, the analysis of economic time series data raises a number of unique inference issues. Based on previous research results, we expect our series data to have stochastic trends. Engle and Granger (1987) explain that co-movements among non-stationary variables may be stationary. Co-movement is known in the econometrics literature through the concept of cointegration. The cointegration relationship among the two series using the Palestinian economic growth as the normalization variable, can be expressed as follows:

$G D P_{t}-\beta_{1} P W R_{t}=e_{t}$

where $G D P_{t}$ and $P W R_{t}$ denote the GDP in Palestine and the inflow of Palestinian workers' remittances from Israel at time $t$, respectively and $e_{t}$ represents the deviation from the equilibrium relationship, i.e., the error correction term. According to Engle and Granger (1987), if the two series are found to be cointegrated then a long-run equilibrium relationship exists and the short and long-run dynamics of the data can be represented through a VECM: ${ }^{3}$

$$
\begin{aligned}
& \Delta G D P_{t}=\alpha_{1}+\lambda_{G D P} e_{t-1}+\sum_{i=1}^{n} \alpha_{11}(i) \Delta G D P_{t-i}+\sum_{i=1}^{n} \alpha_{12}(i) \Delta P W R_{t-i}+u_{1, t} \\
& \Delta P W R_{t}=\alpha_{2}+\lambda_{P W R} e_{t-1}+\sum_{i=1}^{n} \alpha_{21}(i) \Delta G D P_{t-i}+\sum_{i=1}^{n} \alpha_{22}(i) \Delta P W R_{t-i}+u_{2, t}
\end{aligned}
$$

where $\Delta$ is a first difference operator; $u_{1, t}$ and $u_{2, t}$ are random error terms; $e_{t-1}\left(G D P_{t}-\beta_{1} P W R_{t}\right)$ is the one period lagged deviation from the long-run equilibrium relationship, $\alpha_{1}, \alpha_{2}, \alpha_{11}(i), \alpha_{12}(i), \alpha_{21}(i)$ and $\alpha_{22}(i)$ are all short-run dynamics parameters and $\lambda_{G D P}$ and $\lambda_{P W R}$ are known as the speed of adjustment parameters and measure the response of the dependent variables to deviations from the long-run equilibrium relationship. The long-run equilibrium relationship among the two series exists if one or both of the error correction parameters are statistically different from zero.

\footnotetext{
${ }^{3}$ Many empirical studies have found evidence of linear dynamic relationship among variables within different markets (Hassouneh et al., 2015).
} 


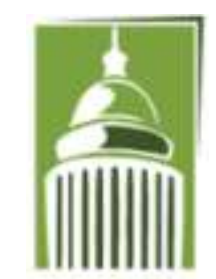

ARF

\section{Global Proceedings Repository \\ American Research Foundation}

ISSN 2476-017X

Available online at http://proceedings.sriweb.org

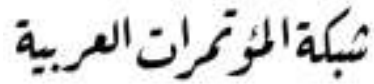

http://arab.kmshare.net/

In this paper, the following estimation strategies have been used. First, standard unit root and cointegration tests are conducted in order to determine whether the series are stationary and whether they are cointegrated, respectively. Second, a VECM is applied.

\section{RESULTS}

Our empirical model utilizes two series of quarterly real GDP and the inflow of Palestinian workers' remittances from Israel covering the period from the fourth quarter 2000 to the third quarter 2016, yielding a total of 64 observations. The two series are obtained from PCBS (2017) and expressed in million Dollars. Remittances to Palestine from Israel are deflated by consumer price index, using 2004 as the base year. The data used in this paper are presented in Figure 1.

Figure 1. Quarterly time series data.

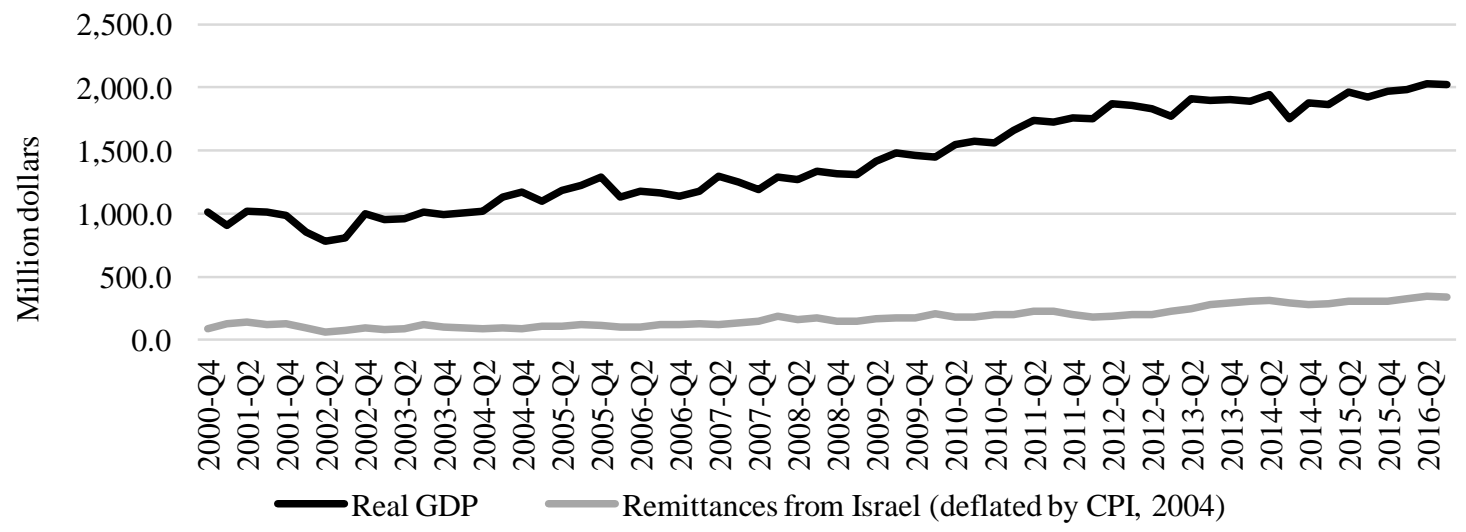

Logarithmic transformations of the data series are used in the empirical implementation. In order to test the unit root property of the real GDP and Palestinian workers' remittances from Israel, augmented Dickey and Fuller (1979), Phillips and Perron (1988) and and KPSS (Kwiatkowski et al., 1992) tests were applied. While, results confirm the presence of a unit root in all logarithmic series, first differences suggest that the null hypothesis of non-stationarity can be rejected at the $5 \%$ significance level for the two series (see Table 1).

Table 1. Unit root test results for the time series used.

\begin{tabular}{lllllll}
\hline Variables & ADF test statistics & \multicolumn{2}{l}{ KPSS test statistics } & \multicolumn{2}{l}{ PP test statistics } \\
\hline & Level & First difference & Level & First difference & Level & First difference \\
\hline GDP & -0.302 & -9.513 & 2.158 & 0.072 & -0.106 & -16.320 \\
\hline PWR & -0.939 & -8.537 & 0.960 & 0.039 & -0.843 & -8.718 \\
\hline $5 \%$ critical value & -2.910 & -2.909 & 0.463 & 0.463 & -2.910 & -2.909 \\
\hline $10 \%$ critical value & -2.592 & -2.592 & 0.347 & 0.347 & -2.592 & -2.592 \\
\hline
\end{tabular}

Note: Each test uses an intercept and no trend. The series are in logarithm form. GDP and PWR stand for Gross

Domestic Product and Palestinian Workers' Remittances from Israel, respectively. 


\section{Global Proceedings Repository \\ American Research Foundation}

ISSN 2476-017X

Available online at http://proceedings.sriweb.org

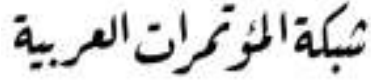

http://arab.kmshare.net/

Following the unit root test, Engle and Granger (1987) cointergration procedure is applied. In doing so, the equilibrium relationship is normalized by the Palestinian economic growth and OLS are used to obtain estimates of the cointegrating parameters (see Table 2). Then and in order to determine if the two variables are actually cointegrated, the deviations from the long-run equilibrium relationship are tested, see Table $3 .{ }^{4}$

Table 2. OLS estimates of the cointegrating relationship.

\begin{tabular}{lll}
\hline Variable & Estimate & Standard Error \\
\hline Intercept & $6.117^{* *}$ & 0.217 \\
\hline$P W R_{t}$ & $0.150^{* *}$ & 0.049 \\
\hline
\end{tabular}

Note: $* *$ denotes statistical significance at the 5 per cent significance level

Table 3. Engle and Granger test for cointegration.

\begin{tabular}{lll}
\hline & Test statistic (lag) & $\mathbf{5 \%}$ critical value \\
\hline DF test & $-4.312(0)$ & -3.370 \\
\hline Notes: critical values are derived from Engle and Yoo $(1987)$
\end{tabular}

Results show that residuals of long-run relationship are stationary and thus the economic growth and workers' remittances are cointegrated and long-run equilibrium relationship between both series exists. More specifically, cointegration test result suggests that there is a long-run positive relationship among the series studied. A $10 \%$ increase in the Palestinian workers' remittance inflows from Israel will be followed by an increase in economic growth $(1.5 \%)$. These results are expected and consistent with previous studies which find that remittance inflows to Palestinian economy affect the output growth (Saad, 2015; Astrup and Dessus, 2005). Once it's concluded that both series are cointegrated, a VECM is estimated. Results are presented in Table $4 .^{5}$

Table 4. Estimation of the Vector Error Correction Model.

\begin{tabular}{lll}
\hline Dependent variable & Real GDP equation & Remittances equation \\
\hline Constant & $0.011(0.007)$ & $0.016(0.016)$ \\
\hline$\Delta G D P_{t-1}$ & $-0.091(0.134)$ & $-0.048(0.315)$ \\
\hline$\Delta P W R_{t-1}$ & $0.099^{*}(0.055)$ & $-0.020(0.130)$ \\
\hline$e_{t-1}$ & $-0.346^{* *}(0.125)$ & $-0.032(0.295)$ \\
\hline
\end{tabular}

${ }^{\mathrm{a}}$ Number in parentheses are standard errors. ${ }^{*}(*)$ denotes statistical significance at the $10(5)$ per cent level.

\footnotetext{
${ }^{4}$ It is worth noting that cointegration test is also conducted using the method developed by Johansen (1988). Result suggests that the hypothesis of no cointegration can be rejected at the 5\% significance level. In this paper, we select Engle and Granger (1987) test which is consistent with the recommendation by Enders (1995, p.385) in the presence of a single cointegration vector.

${ }^{5}$ Akaike Information Criterion (AIC) and Schwartz Bayesian Criterion (SBC) are used to determine the optimal number of lags to be used in the conditional mean model. Results suggest using one lag. Moreover, LM test for autocorrelation is applied and suggest no serial correlation among residuals.
} 


\section{Global Proceedings Repository \\ American Research Foundation}

ISSN 2476-017X

Available online at http://proceedings.sriweb.org

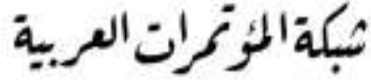

http://arab.kmshare.net/

The error-correction parameter estimates suggest that, while the Palestinian GDP adjust to restore the longrun equilibrium when it is broken, the remittance inflows do not. More specifically, findings provide evidence that GDP is the variable that adjust to deviations from the long-run parity and move to reequilibrate the system, with a speed of adjustment on the order of -0.346 . Results also show that short-run changes in Palestinian workers' remittances have a positive impact on short-run changes in GDP at 10\% significance level. Findings are consistent with the Palestinian environment where the economy is strongly dependent on the Israeli counterpart.

\section{CONCLUSION}

The Israeli labor market is considered as an important employment outlet for the Palestinian labor force. The number of Palestinians working in Israel tends to depend largely on the political environment between Palestine and Israel. This paper aims to shed light on this issue by studying the impact of Palestinian workers' remittances from Israel on Palestinian economic growth using quarterly data over the period 20002016. To do so, Engle and Granger test of cointegration as well as VECM are applied. The cointegration analysis suggests a long-run positive relationship between Palestinian workers' remittances and economic growth in Palestine. The estimated VECM model suggests that, while Palestinian economic growth responds to deviations from the long-run equilibrium relationship, remittance inflows from Israel do not adjust.

These results are found to provide important implications for Palestinian market. More specifically, Palestinian economy is considered sensitive to remittance inflows from Israel, which in turn is highly associated with the political situations between Palestine and Israel. Thus, Palestinian economy and due to the ongoing political tensions is substantially vulnerable to economic shocks. This requires, from Palestinian policy makers, careful consideration to find different means of income that reduce Palestinian economic dependency on Israel and thereby maintain the stability of economy in Palestine.

\section{References}

Astrup, C. and Dessus, S. (2005). Second round of revision Exporting Goods or Exporting Labor?: Longterm Implications for the Palestinian Economy. Review of Middle East Economics and Finance, (3)1:39-61.

Barajas, A., Chami, R., Fullenkamp, C., Gapen, M. and Montiel, P. (2009). Do Workers' Remittances Promote Economic Growth? International Monetary Fund, 153: 1-23.

Chami, R., Fullenkamp, C. and Jahjah, S. (2003). Are Immigrant Remittances Flows a Source of Capital for Development? International Monetary Fund, (52)1: 55-81.

Dickey, D. A. and Fuller, W. A. (1979). Distribution of the estimators for autoregressive time Series with a unit root. Journal of the American Statistical Association, (74) 366: 427-431.

Enders, W. (1995). Applied Econometric Time Series. Iowa State University. Johan Wiley \& Sons, INC. 


\section{Global Proceedings Repository \\ American Research Foundation}

ISSN 2476-017X

Available online at http://proceedings.sriweb.org

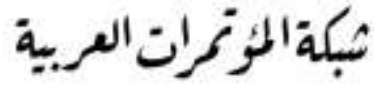

http://arab.kmshare.net/

Engle, R. F. and Granger, C. W. J. (1987). Co-integration and error correction: representation, estimation and testing. Econometrica, (55)2: 251-276.

Engle, R. F. and Yoo, B. S. (1987). Forcasting and testing in cointegrated systems. Journal of Econometrics, (35)1: 143-159.

Farsakh, L. (1998). Palestinian employment in Israel: 1967-1997 A review. Palestine Economic Policy Research Institute. Retrieved from: http://www.mas.ps/files/server/20141811120804-1.pdf (accessed November 2017).

Farsakh, L. (2002). Palestinian Labor Flows to the Israeli Economy: A Finished Story? Journal of Palestine Studies, (32)1: 13-27.

Giuliano, P. and Ruiz-Arranz, M. (2009). Remittances, Financial Development and growth. Journal of Development Economics, (90): 144-152.

Hassouneh, I. (2017). Israeli products in the eyes of Palestinians. IUG Journal of Economics and Business, (25) $1: 1-10$.

Hassouneh, I., Holst, C., Serra, T., von Cramon-Taubadel, S. and Gil, J. M. (2015). Overview of Price Transmission and Reasons for Different Adjustment Patterns across EU Member States. Chapter 3 in S. McCorriston (ed). Food Price Dynamics and Price Adjustment in the EU. Oxford University Press, Oxford.

Jawaid, S. T. and Raza, S. A. (2014). Effects of Workers' Remittances and its Volatility on Economic Growth in South Asia. International Migration, (54)2: 50-68.

Johansen, S. (1988). Statistical analysis of cointegration vectors. Journal of Economic Dynamics and Control, 12: 231-254.

Jongwanich, J. (2007). Workers' Remittances, Economic Growth and Poverty in Developing Asia and the Pacific Countries. UNESCAP Working Paper WP/07/01, Bangkok: ESCAP

Jouini, J. (2015). Economic growth and remittances in Tunisia: Bi-directional causal links. Journal of Policy Modeling, (37) 2: 355-373.

Kandil, M. and Metwally M. F. (1990). The Impact of Migrants' Remittances on the Egyptian Economy. International Migration, 28(2): 159-180.

Kwiatkowski, D., Phillips, C. B., Schmidt, P. and Shin, Y. (1992) Testing the null hypothesis of stationarity against the alternative of a unit root: How sure are we that economic time series have a unit root? Journal of Econometrics, 54: 159-178.

Lentin, R. (2008). Thinking Palestine. London and New York: Zed Books: 1-22. 


\section{Global Proceedings Repository \\ American Research Foundation}

ISSN 2476-017X

Available online at http://proceedings.sriweb.org

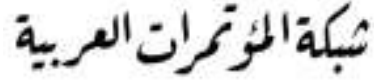

http://arab.kmshare.net/

Mayer, D. and Shera A. (2017). The impact of remittances on economic growth: An econometric model. EconomiA, 18(2): 147-155.

Nsiah, C. and Fayissa B. (2011). Remittances and economic growth in Africa, Asia, and Latin AmericanCaribbean countries: a panel unit root and panel cointegration analysis. Journal of Economics and Finance, 37: 424-441.

PCBS, (2017). Dataset. http://www.pcbs.gov.ps/. Accessed October 2017.

Phillips, P. C. and Perron P. (1988). Testing for a unit root in time series regression. Biometrika, 75: 335346.

Pradhan, G., Upadhyay, M. and Upadhyaya, K. (2008). Remittances and economic growth in developing countries. The European Journal of Development Research, (20)3: 497-506.

Saad, A. (2015). The Impact of Remittances on Key Macroeconomic Variables: The Case of Palestine. The Palestine Economic Policy Research Institute. Retrieved from: http://www.mas.ps/files/server/20152304160443-1.pdf (accessed October 2017).

Smith, C. D. (2010). Palestine and the Arab-Israeli conflict: a History with Documents. Palgrave Macmillan, Basingstoke.

Spatafora, N. (2005). Two current issues facing developing countries. World Economic Outlook, International Monetary Fund, Washington, DC.

Waheed, A. and Aleem A. (2008). Workers' remittances and economic growth: empirical evidence from Pakistan. Journal of Social Science and Humanities, 47 (1): 1-12.

World Bank. (2017) Migration and remittances: Recent developments and outlook. Migration and development brief; no. 27. Washington, D.C.: World Bank Group. Retrieved from: http://pubdocs.worldbank.org/en/992371492706371662/MigrationandDevelopmentBrief27.pdf 


\section{Global Proceedings Repository \\ American Research Foundation}

ISSN 2476-017X

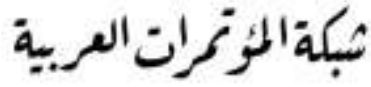

http://arab.kmshare.net/

Available online at http://proceedings.sriweb.org 